\section{Visual acuity and intraocular pressure after high-dose intravitreal triamcinolone acetonide in selected ocular diseases}

JB Jonas and F Schlichtenbrede

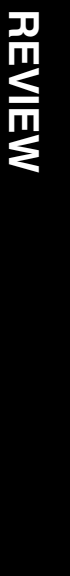

endothelial growth factor blocking drugs. For diseases with intraretinal oedema, the rule of thumb may be that intravitreal triamcinolone increases vision as much as retinal ischaemia and tissue destruction by the underlying disease allow it. The rise in intraocular pressure is higher in relatively young patients with uveitis than in elderly patients with other reasons for macular oedema.

Eye (2008) 22, 869-873; doi:10.1038/sj.eye.6702734; published online 16 February 2007

Keywords: intravitreal steroids; intravitreal triamcinolone; macular oedema; age-related macular degeneration; uveitis; intraocular pressure

occlusion, central retinal vein occlusion, uveitis, and pseudophakic cystoid macular oedema. Rise in intraocular pressure was significantly higher in relatively young patients with uveitis than in any other patient group.

Conclusions Improvement in vision after intravitreal triamcinolone monotherapy is highest in non-ischaemic diseases with an intraretinal macular oedema such as pseudophakic cystoid macular oedema; it is lower in partially ischaemic diseases with intraretinal macular oedema such as diabetic macular oedema or retinal vein occlusions; and it is lowest in diseases with a primarily subretinal location of the disease such as exudative age-related macular degeneration. For the latter diseases, intravitreal triamcinolone monotherapy is, therefore, no longer up-to-date, particularly with the upcoming intravitreal application of vascular

\section{Introduction}

Following Robert Machemer, Gholam Peyman, and others, ${ }^{1-6}$ intravitreal triamcinolone acetonide has increasingly been used in recent studies as treatment for other intraocular proliferative, oedematous, and neovascular diseases, such as diffuse diabetic macular oedema, ${ }^{7-13}$ central retinal vein occlusion, ${ }^{14-17}$ branch retinal vein occlusion, ${ }^{18-20}$ chronic uveitis, ${ }^{21-25}$ persistent pseudophakic cystoid macular oedema, ${ }^{26-29}$ exudative age-related macular degeneration, ${ }^{30-44}$ and other diseases. ${ }^{6}$ It has remained unclear so far, whether the various ocular disorders differ in their response to intravitreal triamcinolone acetonide in terms of an increase in visual acuity and a rise in intraocular pressure. It was, therefore, the

\section{Department of}

Ophthalmology, Faculty of Clinical Medicine Mannheim of the University, Heidelberg, Germany

Correspondence: JB Jonas, Department of Ophthalmology, Faculty of Clinical Medicine, Mannheim, Heidelberg University,

Theodor-Kutzer-Ufer 1-3, Mannheim, 68167,

Germany

Tel: + 49621383 2242;

Fax: + 496213833803

E-mail: Jost.Jonas@

augen.ma.uni-heidelberg.de

Received: 21 November 2006

Accepted in revised form: 28 December 2006

Published online:

16 February 2007
Proprietary interest: None 
purpose of the present review to compare groups of patients with selected ocular diseases with respect to the effect of intravitreal triamcinolone on visual acuity and intraocular pressure.

In the review, 359 eyes with diffuse diabetic macular oedema $(n=102)$, progressive exudative age-related macular degeneration with non-classic subfoveal neovascularization $(n=216)$, uveitis $(n=10)$, branch retinal vein occlusion $(n=12)$, central retinal vein occlusion $(n=12)$, and pseudophakic cystoid macular oedema $(n=7)$ were included (Table 1$)$. All patients received an intravitreal high-dose injection of triamcinolone acetonide of about $20 \mathrm{mg}$ as single and only procedure and had been evaluated in previous single-disease studies. $6,7,14,18,21,26,30,45,46,8$ Age was significantly lowest in the uveitis group than in the other groups.

Table 1 Visual acuity and intraocular pressure after intravitreal injection of triamcinolone acetonide for various diseases

\begin{tabular}{|c|c|c|c|c|c|c|}
\hline & $\begin{array}{l}\text { Exudative age-related } \\
\text { macular degeneration }\end{array}$ & $\begin{array}{l}\text { Diffuse diabetic } \\
\text { macular oedema }\end{array}$ & Uveitis & $\begin{array}{l}\text { Branch retinal } \\
\text { vein occlusion }\end{array}$ & $\begin{array}{l}\text { Central retinal } \\
\text { occlusion }\end{array}$ & $\begin{array}{l}\text { Pseudophakic cystoid } \\
\text { vein macular oedema }\end{array}$ \\
\hline$n$ (eyes) & 216 & 102 & 10 & 12 & 12 & 7 \\
\hline Females/males & $135 / 81$ & $57 / 45$ & $8 / 2$ & $9 / 3$ & $3 / 9$ & $6 / 1$ \\
\hline Age (years) & $76.2 \pm 11.7$ & $66.2 \pm 10.1$ & $56.9 \pm 22.2$ & $73.0 \pm 7.71$ & $66.2 \pm 13.0$ & $74.0 \pm 6.0$ \\
\hline $\begin{array}{l}\text { Refractive error } \\
\text { (dioptres) }\end{array}$ & $0.58 \pm 1.99$ & $0.51 \pm 1.32$ & $0.76 \pm 2.24$ & $0.71 \pm 1.46$ & $0.92 \pm 2.28$ & $0.21 \pm 1.00$ \\
\hline \multicolumn{7}{|l|}{ Visual acuity baseline } \\
\hline LogMa & $0.88 \pm 0.42$ & $0.88 \pm 0.34$ & $0.63 \pm 0.31$ & $0.79 \pm 0.60$ & $1.05 \pm 0.62$ & $0.59 \pm 0.23$ \\
\hline Snellen acuity & $0.19 \pm 0.14$ & $0.17 \pm 0.13$ & $0.29 \pm 0.22$ & $0.24 \pm 0.14$ & $0.16 \pm 0.16$ & $0.29 \pm 0.12$ \\
\hline \multicolumn{7}{|l|}{ Maximal } \\
\hline LogMar & $0.78 \pm 0.42$ & $0.64 \pm 0.34$ & $0.34 \pm 0.29$ & $0.56 \pm 0.72$ & $0.79 \pm 0.66$ & $0.29 \pm 0.17$ \\
\hline Snellen acuity & $0.23 \pm 0.18$ & $0.30 \pm 0.20$ & $0.55 \pm 0.32$ & $0.45 \pm 0.28$ & $0.30 \pm 0.25$ & $0.54 \pm 0.19$ \\
\hline \multicolumn{7}{|l|}{ End of FU } \\
\hline LogMar & $1.06 \pm 0.50$ & $0.89 \pm 0.41$ & $0.57 \pm 0.38$ & $0.75 \pm 0.66$ & $1.28 \pm 0.69$ & $0.44 \pm 0.13$ \\
\hline Snellen acuity & $0.14 \pm 0.14$ & $0.18 \pm 0.15$ & $0.38 \pm 0.36$ & $0.28 \pm 0.18$ & $0.11 \pm 0.14$ & $0.38 \pm 0.11$ \\
\hline \multicolumn{7}{|l|}{ Maximal gain } \\
\hline LogMar & $-0.10 \pm 0.30$ & $-0.24 \pm 0.22$ & $-0.29 \pm 0.19$ & $-0.22 \pm 0.23$ & $-0.26 \pm 0.26$ & $-0.30 \pm 0.22$ \\
\hline Snellen lines & $0.96 \pm 2.84$ & $2.48 \pm 2.22$ & $2.90 \pm 1.91$ & $2.33 \pm 2.19$ & $2.75 \pm 2.67$ & $3.01 \pm 2.17$ \\
\hline \multicolumn{7}{|l|}{ Baseline to end of FU } \\
\hline LogMar & $0.18 \pm 0.48$ & $0.00 \pm 0.31$ & $-0.06 \pm 0.28$ & $-0.04 \pm 0.20$ & $0.23 \pm 0.34$ & $-0.15 \pm 0.19$ \\
\hline Snellen lines & $-1.63 \pm 4.03$ & $0.00 \pm 2.89$ & $0.60 \pm 2.84$ & $0.42 \pm 1.93$ & $-1.83 \pm 2.86$ & $1.57 \pm 1.90$ \\
\hline \multicolumn{7}{|c|}{ Intraocular pressure $(\mathrm{mm} \mathrm{Hg})$} \\
\hline Baseline & $15.3 \pm 2.9$ & $15.3 \pm 3.7$ & $12.1 \pm 4.2$ & $16.5 \pm 2.7$ & $15.0 \pm 2.2$ & $16.8 \pm 2.9$ \\
\hline Maximal during & $21.8 \pm 7.3$ & $21.5 \pm 5.9$ & $26.9 \pm 11.1$ & $21.8 \pm 4.5$ & $23.8 \pm 8.2$ & $21.7 \pm 4.8$ \\
\hline \multicolumn{7}{|l|}{ FU } \\
\hline End of FU & $17.0 \pm 5.3$ & $16.4 \pm 4.1$ & $15.8 \pm 6.0$ & $16.9 \pm 1.5$ & $16.4 \pm 4.3$ & $18.5 \pm 6.3$ \\
\hline Maximal increase & $6.4 \pm 6.9$ & $5.9 \pm 5.8$ & $11.3 \pm 7.0$ & $5.4 \pm 4.2$ & $9.1 \pm 8.7$ & $5.5 \pm 6.1$ \\
\hline \multicolumn{7}{|l|}{ Maximal IOP } \\
\hline$>21 \mathrm{~mm} \mathrm{Hg}$ & $83 / 216(38 \%)$ & $45 / 102(44 \%)$ & $5 / 10(50 \%)$ & $6 / 12(50 \%)$ & $4 / 12(33 \%)$ & $2 / 7(29 \%)$ \\
\hline$>25 \mathrm{~mm} \mathrm{Hg}$ & $48 / 216(22 \%)$ & $18 / 102(18 \%)$ & $4 / 10(40 \%)$ & $3 / 12(25 \%)$ & 4 / $12(33 \%)$ & $2 / 7(29 \%)$ \\
\hline$>30 \mathrm{~mm} \mathrm{Hg}$ & $25 / 216(12 \%)$ & $6 / 102(6 \%)$ & $4 / 10(40 \%)$ & $1 / 12(8 \%)$ & $2 / 12(17 \%)$ & $0 / 7(0 \%)$ \\
\hline$>35 \mathrm{~mm} \mathrm{Hg}$ & $12 / 216(6 \%)$ & $3 / 102(3 \%)$ & $2 / 10(20 \%)$ & $0 / 12(0 \%)$ & $1 / 12(8 \%)$ & $0 / 7(0 \%)$ \\
\hline$>40 \mathrm{~mm} \mathrm{Hg}$ & $4 / 216(2 \%)$ & $1 / 102(1 \%)$ & $1 / 10(10 \%)$ & $0 / 12(0 \%)$ & $1 / 12(8 \%)$ & $0 / 7(0 \%)$ \\
\hline Increase by & $105 / 216(49 \%)$ & $47 / 102(46 \%)$ & $7 / 10(70 \%)$ & $6 / 12(50 \%)$ & $7 / 12(58 \%)$ & $3 / 7(43 \%)$ \\
\hline \multicolumn{7}{|l|}{$>5 \mathrm{~mm} \mathrm{Hg}$} \\
\hline$>10 \mathrm{~mm} \mathrm{Hg}$ & $44 / 216(20 \%)$ & $18 / 102(18 \%)$ & $7 / 10(70 \%)$ & $1 / 12(8 \%)$ & $4 / 12(33 \%)$ & $2 / 7(29 \%)$ \\
\hline$>15 \mathrm{~mm} \mathrm{Hg}$ & $22 / 216(10 \%)$ & $7 / 102(7 \%)$ & $3 / 10(30 \%)$ & $1 / 12(8 \%)$ & $3 / 12(25 \%)$ & $0 / 7(0 \%)$ \\
\hline$>20 \mathrm{~mm} \mathrm{Hg}$ & $9 / 216(4 \%)$ & $3 / 102(3 \%)$ & $2 / 10(20 \%)$ & $0 / 12(0 \%)$ & $1 / 12(8 \%)$ & $0 / 7(0 \%)$ \\
\hline$>25 \mathrm{~mm} \mathrm{Hg}$ & $4 / 216(2 \%)$ & $2 / 102(2 \%)$ & $1 / 10(10 \%)$ & $0 / 12(0)$ & $1 / 12(8 \%)$ & $0 / 7(0 \%)$ \\
\hline$>30 \mathrm{~mm} \mathrm{Hg}$ & $1 / 216(1 \%)$ & $0 / 102(0 \%)$ & $1 / 10(10 \%)$ & $0 / 12(0)$ & $0 / 12(0 \%)$ & $0 / 7(0 \%$ \\
\hline References & $12.33-46$ & $7.15-20$ & $10.26-29$ & $8.21-23$ & 9.24 .25 & $11.30-32$ \\
\hline
\end{tabular}


Comparing the different patient groups with each other revealed that the maximal increase in visual acuity during follow-up was significantly lower in the AMD group $(-0.10 \pm 0.30 \log$ Mar units) than in the diabetic macular oedema group $(-0.24 \pm 0.22 \log$ Mar units $)$ $(P<0.001)$, the branch retinal vein occlusion group $(-0.22 \pm 0.23 \log$ Mar units $)(P=0.032)$, the central retinal vein occlusion group $(-0.26 \pm 0.26 \log$ MAR units $)$ $(P=0.032)$, the uveitis group $(-0.29 \pm 0.19 \log$ Mar units $)$, and the pseudophakic cystoid macular oedema $(-0.30 \pm 0.22 \log$ Mar units $)(P=0.042)$. The other study groups did not vary statistically and significantly in the maximal gain in visual acuity although the gain in visual acuity was slightly higher in the uveitis group and the pseudophakic cystoid macular oedema group than in the diabetic macular oedema group.

The intraocular pressure rise was significantly higher in the uveitis group $(11.3 \pm 7.0 \mathrm{~mm} \mathrm{Hg})$ than in the agerelated macular degeneration group $(6.4 \pm 6.9 \mathrm{~mm} \mathrm{Hg})$ $(P=0.007)$, the diabetic macular oedema group $(5.9 \pm 5.8 \mathrm{~mm} \mathrm{Hg})(P=0.007)$, the branch retinal vein occlusion group $(5.4 \pm 4.2 \mathrm{~mm} \mathrm{Hg})(P=0.021)$, and the pseudophakic cystoid macular oedema group $(5.5 \pm 6.1 \mathrm{~mm} \mathrm{Hg})(P=0.033)$. The non-uveitis study groups did not vary significantly in the amount of an increase in intraocular pressure $(P=0.91)$.

Correspondingly, the frequency of an increase in intraocular pressure by more than $10 \mathrm{~mm} \mathrm{Hg}$ was significantly higher in the uveitis group than in the agerelated macular degeneration group $(P=0.001)$ and the diabetic macular oedema group $(P=0.001)$. The other study groups, except the uveitis group did not vary significantly $(P>0.10)$ in the frequency of a rise in the intraocular pressure.

The results of the present review suggest that the best response in terms of gain in visual acuity after the intravitreal injection of triamcinolone acetonide can be found in eyes with intraretinal oedematous diseases without marked ischaemia such as pseudophakic cystoid macular oedema and uveitic cystoid macular oedema. A moderate increase was detected in eyes with intraretinal oedema and variable macular ischemia such as in diffuse diabetic macular oedema, branch retinal vein occlusion, and central retinal vein occlusion. The visual acuity was lowest in patients with an unhealthy chorioretinal interface, as in exudative age-related degeneration. The results of the present study additionally suggest that the rise in the intraocular pressure was significantly the highest and occurred most frequently in the uveitis group. Simultaneously, the patients of the uveitis study group were significantly younger than the remaining patients. It agrees with a recent study in which the rise in intraocular pressure reaction after an intravitreal injection of triamcinolone acetonide was significantly associated with younger age of the patients. ${ }^{47}$ Regarding the uveitis associated pathophysiologic changes such as an increased viscosity of the aqueous humour and inflammatory changes in the trabecular meshwork, one may take into account that besides younger age the uveitic disease by itself might have been the reason or an additional reason for the higher intraocular pressure response in the uveitis group compared with the other study groups.

In conclusion, the increase in visual acuity after intravitreal triamcinolone acetonide may be highest in non-ischaemic diseases with an intraretinal macular oedema such as pseudophakic cystoid macular oedema and uveitis; the increase in visual acuity may be moderate in partially ischaemic diseases with intraretinal macular oedema, such as diabetic macular oedema; and the increase in visual acuity may be lowest in diseases with a primarily subretinal location of the disease such as exudative age-related macular degeneration. The rise in intraocular pressure as complication of intravitreal triamcinolone acetonide may be higher in relatively young patients with uveitis than in elderly patients with other reasons for macular oedema.

\section{References}

1 Graham RO, Peyman GA. Intravitreal injection of dexamethasone. Treatment of experimentally induced endophthalmitis. Arch Ophthalmol 1974; 92: 149-154.

2 Machemer R, Sugita G, Tano Y. Treatment of intraocular proliferations with intravitreal steroids. Trans Am Ophthalmol Soc 1979; 77: 171-180.

3 Tano Y, Chandler D, Machemer R. Treatment of intraocular proliferation with intravitreal injection of tramcinolone acetonide. Am J Ophthalmol 1980; 90: 810-816.

4 Tano Y, Sugita G, Abrams G, Machemer R. Inhibition of intraocular proliferation with intravitreal corticosteroid. Am J Ophthalmol 1980; 89: 131-136.

5 Machemer R. Five cases in which a depot steroid (hydrocortisone acetate and methylprednisolone acetate) was injected into the eye. Retina 1996; 16: 166-167.

6 Jonas JB, Kreissig I, Degenring RF. Intravitreal triamcinolone acetonide for treatment of intraocular proliferative, exudative and angiogenic diseases. Prog Ret Eye Res 2005; 5: 587-611.

7 Jonas JB, Kreissig I, Söfker A, Degenring RF. Intravitreal injection of triamcinolone acetonide for diabetic macular oedema. Arch Ophthalmol 2003; 121: 57-61.

8 Jonas JB, Söfker A. Intraocular injection of crystalline cortisone as adjunctive treatment of diabetic macular oedema. Am J Ophthalmol 2001; 132: 425-427.

9 Martidis A, Duker JS, Greenberg PB, Rogers AH, Puliafito CA, Reichel E et al. Intravitreal triamcinolone for refractory diabetic macular oedema. Ophthalmology 2002; 109: 920-927. 
10 Massin P, Audren F, Haouchine B, Erginay A, Bergmann JF, Benosman $\mathrm{R}$ et al. Intravitreal triamcinolone acetonide for diabetic diffuse macular oedema: preliminary results of a prospective controlled trial. Ophthalmology 2004; 111: 218-224.

11 Karacorlu M, Ozdemir H, Karacorlu S, Alacali N, Mudun B, Burumcek E. Intravitreal triamcinolone as a primary therapy in diabetic macular oedema. Eye 2005; 19: 382-386.

12 Spandau UHM, Derse M, Schmitz-Valckenberg P, Papoulis $\mathrm{C}$, Jonas JB. Dosage-dependency of intravitreal triamcinolone acetonide as treatment for diabetic macular oedema. Br J Ophthalmol 2005; 89: 999-1003.

13 Jonas JB, Martus P, Degenring RF, Kreissig I, Akkoyun I. Predictive factors for visual acuity change after intravitreal triamcinolone for diabetic macular oedema. Arch Ophthalmol 2005; 123: 1338-1343.

14 Jonas JB, Kreissig I, Degenring RF. Intravitreal triamcinolone acetonide as treatment of macular oedema in central retinal vein occlusion. Graef Arch Clin Exp Ophthalmol 2002; 240: 782-783.

15 Greenberg PB, Martidis A, Rogers AH, Duker JS, Reichel E. Intravitreal triamcinolone acetonide for macular oedema due to central retinal vein occlusion. Br J Ophthalmol 2002; 86: $247-248$.

16 Ip MS, Kumar KS. Intravitreous triamcinolone acetonide as treatment for macular oedema from central retinal vein occlusion. Arch Ophthalmol 2002; 120: 1217-1219.

17 Park $\mathrm{CH}$, Jaffe GJ, Fekrat S. Intravitreal triamcinolone acetonide in eyes with cystoid macular oedema associated with central retinal vein occlusion. Am J Ophthalmol 2003; 136: 419-425.

18 Jonas JB, Akkoyun I, Kamppeter B, Kreissig I, Degenring RF. Intravitreal triamcinolone acetonide as treatment of branch retinal vein occlusion. Eye 2005; 19: 65-71.

19 Degenring RF, Kamppeter B, Kreissig I, Jonas JB. Morphologic and functional changes after intravitreal triamcinolone acetonide for retinal vein occlusion. Acta Ophthalmol 2003; 81: 399-401.

20 Chen SD, Lochhead J, Patel CK, Frith P. Intravitreal triamcinolone acetonide for ischaemic macular oedema caused by branch retinal vein occlusion. Br J Ophthalmol 2004; 88: 154-155.

21 Degenring RF, Jonas JB. Intravitreal injection of triamcinolone acetonide as treatment of chronic uveitis. $\mathrm{Br} J$ Ophthalmol 2003; 87: 361.

22 Benitez Del Castillo Sanchez JM, Garcia Sanchez J. [Intravitreal injection of triamcinolone acetonide in non infectious uveitis]. Arch Soc Esp Oftalmol 2001; 76: 661-664.

23 Martidis A, Duker JS, Puliafito CA. Intravitreal triamcinolone for refractory cystoid macular oedema secondary to birdshot retinochoroidopathy. Arch Ophthalmol 2001; 119: 1380-1383.

24 Young S, Larkin G, Branley M, Lightman S. Safety and efficacy of intravitreal triamcinolone for cystoid macular oedema in uveitis. Clin Exp Ophthalmol 2001; 29: 2-6.

25 Antcliff RJ, Spalton DJ, Stanford MR, Graham EM, Ffytche TJ, Marshall J. Intravitreal triamcinolone for uveitic cystoid macular oedema: an optical coherence tomography study. Ophthalmology 2001; 108: 765-772.

26 Jonas JB, Kreissig I, Degenring RF. Intravitreal triamcinolone acetonide for pseudophakic cystoid macular oedema. Am J Ophthalmol 2003; 136: 384-386.
27 Benhamou N, Massin P, Haouchine B, Audren F, Tadayoni $\mathrm{R}$, Gaudric A. Intravitreal triamcinolone for refractory pseudophakic macular oedema. Am J Ophthalmol 2003; 135: 246-249.

28 Conway MD, Canakis C, Livir-Rallatos C, Peyman GA. Intravitreal triamcinolone acetonide for refractory chronic pseudophakic cystoid macular oedema. J Cataract Refract Surg 2003; 29: 27-33.

29 Karacorlu M, Ozdemir H, Karacorlu S. Intravitreal triamcinolone acetonide for the treatment of chronic pseudophakic cystoid macular oedema. Acta Ophthalmol Scand 2003; 81: 648-652.

30 Jonas JB, Degenring RF, Kreissig I, Friedemann T, Akkoyun I. Exudative age-related macular degeneration treated by intravitreal triamcinolone acetonide. A prospective comparative non-randomized study. Eye 2005; 19: 163-170.

31 Penfold PL, Gyory JF, Hunyor AB, Billson FA. Exudative macular degeneration and intravitreal triamcinolone. A pilot study. Aust NZ J Ophthalmol 1995; 23: 293-298.

32 Challa JK, Gillies MC, Penfold PL, Gyory JF, Hunyor AB, Billson FA. Exudative macular degeneration and intravitreal triamcinolone: 18 month follow up. Aust N Z J Ophthalmol 1998; 26: 277-281.

33 Danis RP, Ciulla TA, Pratt LM, Anliker W. Intravitreal triamcinolone acetonide in exudative age-related macular degeneration. Retina 2000; 20: 244-250.

34 Jonas JB, Kreissig I, Degenring RF. Repeated intravitreal injections of triamcinolone acetonide as treatment of progressive exudative age-related macular degeneration. Graef Arch Clin Exp Ophthalmol 2002; 240: 873-874.

35 Ranson NT, Danis RP, Ciulla TA, Pratt L. Intravitreal triamcinolone in subfoveal recurrence of choroidal neovascularisation after laser treatment in macular degeneration. Br J Ophthalmol 2002; 86: 527-529.

36 Penfold PL. Intravitreal triamcinolone in recurrence of choroidal neovascularization. Br J Ophthalmol 2002; 86: 600-601.

37 Gillies MC, Simpson JM, Luo W, Penfold P, Hunyor AB, Chua $\mathrm{W}$ et al. A randomized clinical trial of a single dose of intravitreal triamcinolone acetonide for neovascular agerelated macular degeneration: one-year results. Arch Ophthalmol 2003; 121: 667-673.

38 Jonas JB, Kreissig I, Hugger P, Sauder G, Panda-Jonas S, Degenring $\mathrm{R}$. Intravitreal triamcinolone acetonide for exudative age-related macular degeneration. $\mathrm{Br} \mathrm{J}$ Ophthalmol 2003; 87: 462-468.

39 Spaide RF, Sorenson J, Maranan L. Combined photodynamic therapy with verteporfin and intravitreal triamcinolone acetonide for choroidal neovascularization. Ophthalmology 2003; 110: 1517-1525.

40 Jonas JB, Akkoyun I, Budde WM, Kreissig I, Degenring RF. Intravitreal re-injection of triamcinolone for exudative agerelated macular degeneration. Arch Ophthalmol 2004; 122: 218-222.

41 Jonas JB, Degenring RF, Kreissig I, Friedemann T, Akkoyun I. Exudative age-related macular degeneration treated by intravitreal triamcinolone acetonide. A prospective comparative non-randomized study. Eye 2005; 19: 163-170.

42 Jonas JB, Kreissig I, Degenring RF. Factors influencing visual acuity after intravitreal triamcinolone acetonide as treatment of exudative age-related macular degeneration. $\mathrm{Br}$ J Ophthalmol 2004; 88: 1557-1562. 
43 Rechtman E, Danis RP, Pratt LM, Harris A. Intravitreal triamcinolone with photodynamic therapy for subfoveal choroidal neovascularisation in age related macular degeneration. Br J Ophthalmol 2004; 88: 344-347.

44 Jonas JB, Spandau UH, Harder B, Vossmerbaeumer U, Kamppeter BA. Inter-eye difference in exudative age-related macular degeneration with minimally classic or occult subfoveal neovascularisation after unilateral intravitreal injection of triamcinolone acetonide. Am J Ophthalmol 2005; 139: 1073-1079.
45 Jonas JB, Kreissig I, Degenring RF. Endophthalmitis after intravitreal injection of triamcinolone acetonide. Arch Ophthalmol 2003; 121: 1663-1664.

46 Spandau UHM, Derse M, Schmitz-Valckenberg P, Papoulis C, Sagstetter BU, Stiefvater KH et al. Measurement of triamcinolone acetonide concentration after filtering of solvent agent. Am J Ophthalmol 2005; 139: 712-713.

47 Jonas JB, Degenring RF, Kreissig I, Akkoyun I, Kamppeter BA. Intraocular pressure elevation after intravitreal triamcinolone acetonide injection. Ophthalmology 2005; 112: 593-598. 